\title{
An asymmetric route to the construction of the bicyclic framework of marine eicosanoids Bacillariolides
}

\author{
Saikat Sinha, Tanurima Bhaumik, and Subrata Ghosh* \\ Department of Organic Chemistry, Indian Association for the Cultivation of Science, Jadavpur, \\ Kolkata 700 032, India \\ E-mail: ocsg@mahendra.iacs.res.in
}

Dedicated to Professor S. Swaminathan on the occasion of his $80^{\text {th }}$ birthday

(received 31 Aug 04; accepted 14 Oct 04; published on the web 02 Nov 04)

\begin{abstract}
A stereoselective route to the synthesis of $\gamma$-lactone fused cyclopentenes, the core structure of the marine eicosanoids bacillariolides, is described. The key step involves ring closing metathesis of 1,-6-diene built from D-mannitol to construct the cyclopentene unit in enantiomerically pure form.
\end{abstract}

Keywords: Asymmetric synthesis, eicosanoids, butanolides, olefin metathesis

\section{Introduction}

Bacillariolides 1-3 are structurally unique eicosanoids possessing a $\gamma$-lactone fused cyclopentanol framework with four contiguous stereocenters. Bacillariolide I $\mathbf{1}$ and bacillariolide II 2 were isolated from the marine diatom, pseudonitzscha multiseries, while bacillariolide III $\mathbf{3}$ was isolated from the culture medium of the same marine diatom and is considered a metabolite obtained from oxidative cleavage of the side chain. The natural product 1 was reported as an inhibitor of phospholipase A2 ( $\left.\mathrm{PLA}_{2}\right)$ while the biological functions of bacillariolides $\mathbf{2}$ and $\mathbf{3}$ are under investigation. $\mathrm{PLA}_{2}$ is one of the enzymes that metabolize lipids liberating fatty acids which through a cyclooxygenase pathway leads to the formation of prostaglandins and leukotrienes, which are known to be potent mediators of inflammation. Thus, inhibition of PLA 2 is considered to be an attractive target for the design of antiinflammatory drugs. Due to the biological potential and stereochemically accessible structure, bacillariolides have become the target of synthetic investigations. ${ }^{3}$ We herein report an asymmetric approach for the synthesis of bacillariolides starting from D-mannitol. 


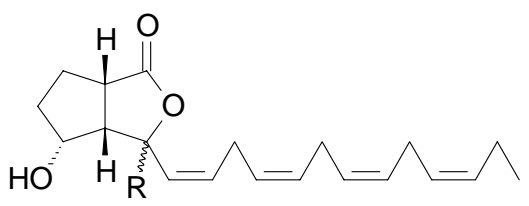

1, $\mathrm{R}=\alpha-\mathrm{H}$

2, $\mathrm{R}=\beta-\mathrm{H}$

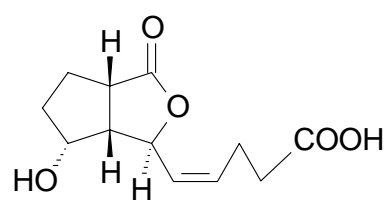

3

\section{Results and Discussion}

The key concept employed in this approach relies on the construction of the cyclopentane ring of bacillariolides through ring closing metathesis $(\mathrm{RCM})^{4}$ of a diene built from a carbohydrate derivative. The carbohydrate derivative is chosen in a way so as to provide the lactone unit. RCM of dienes derived from carbohydrates has been shown to be an efficient approach ${ }^{4-6}$ for the synthesis of enantio-pure cyclic systems of various ring size. This concept has recently been employed by us $^{6}$ to construct substituted cyclopentenols, the core structural unit of the carbocyclic nucleosides carbovir and abacavir. We envisaged that the cyclopentene derivative 4 would be an ideal intermediate for the synthesis of bacillariolides (Scheme 1) as hydroxyl group can be introduced through intramolecular hydroboration by alkoxyborane generated in situ from the hydroxymethyl group in $4(\mathrm{R}=\mathrm{H})$ during reaction with borane. A sequence of $\mathrm{RCM}$ followed by lactonisation in the diene 5 will provide this bicyclic intermediate 4 . The diene 5 may be expected to be available from the known unsaturated ester $\mathbf{6}$ which in turn is available from Dmannitol.

The unsaturated ester 6 along with its diastereoisomer 10 was obtained from D-mannitol derivative $7^{7}$ following the procedure developed by us ${ }^{8}$ as depicted in Scheme 2. Wittig-Horner reaction of the aldehyde generated in situ from periodate cleavage of the diol 7 afforded the unsaturated ester 8 . The ester 8 was reduced with $\mathrm{LiAIH}_{4}$ at $-60{ }^{\circ} \mathrm{C}$ to afford the allyl alcohol $\mathbf{9}$.

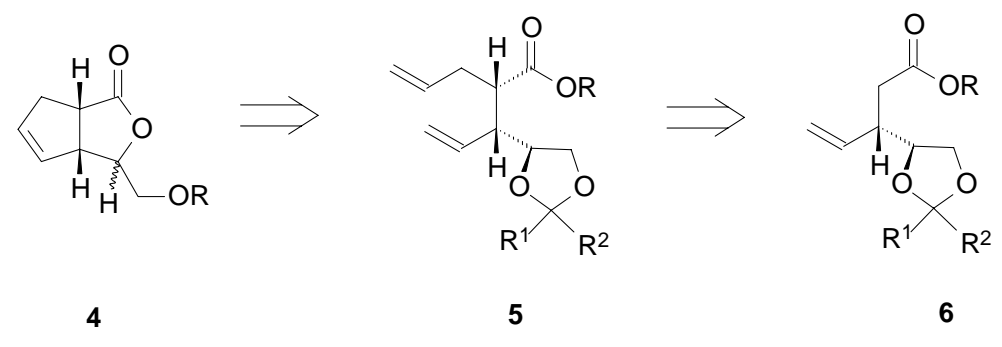

\section{Scheme 1}

Ortho-ester Claisen rearrangement of this allylic alcohol produced a mixture of chromatographically separable unsaturated esters $\mathbf{6}$ and $\mathbf{1 0 .}$ 


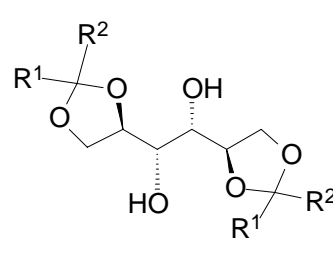

7

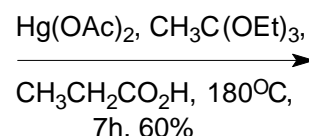

$7 \mathrm{~h}, 60 \%$ (i) $\mathrm{NaIO}_{4}, \mathrm{CH}_{3} \mathrm{CN} / \mathrm{H}_{2} \mathrm{O}$ ( 3:2),

(EtO) ${ }_{2} \mathrm{P}(\mathrm{O}) \mathrm{CH}_{2} \mathrm{CO}_{2} \mathrm{Et}, \mathrm{K}_{2} \mathrm{CO}_{3}$,

$0^{\circ} \mathrm{C}-\mathrm{rt}, 16 \mathrm{~h}, 74 \%$

(ii) $\mathrm{LiAlH}_{4}, \mathrm{Et}_{2} \mathrm{O},-60^{\circ} \mathrm{C}, 42 \%$

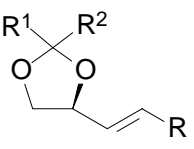

$\mathrm{R}^{1}, \mathrm{R}^{2}=-\left(\mathrm{CH}_{2}\right)_{5}-$

$8 \mathrm{R}=\mathrm{CO}_{2} \mathrm{Et}$

$9 \mathrm{R}=\mathrm{CH}_{2} \mathrm{OH}$

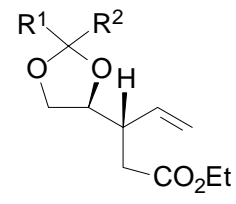

6

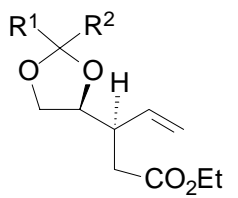

10

\section{Scheme 2}

In connection to a different project, ${ }^{9}$ alkylation of the enolate generated from the unsaturated ester 6 was investigated. It was found that such alkylation results in the synthesis of products in which the incoming electrophile occupies a position anti to the vinyl group. Thus allylation of the enolate of the ester 6 was unlikely to provide the required cis-diene 5 . To circumvent this problem we decided to use the malonate derivative 11. The malonate derivative $\mathbf{1 1}$ was prepared in $75 \%$ yield from the lithium enolate of the unsaturated ester 6 with ethyl chloroformate (Scheme 3). Allylation of the malonate derivative 11 with allyl bromide afforded the diene 12 in $78 \%$ yield. Ring closure of 12 proceeded smoothly when treated with the Grubbs' catalyst $\left(\mathrm{PCy}_{3}\right)_{2} \mathrm{Cl}_{2} \mathrm{Ru}=\mathrm{CHPh} 13$ in benzene at $60^{\circ} \mathrm{C}$ to produce the cyclopentene 14 in $83 \%$ yield. Treatment of 14 with $80 \%$ aqueous acetic acid at $80-85^{\circ} \mathrm{C}$ led to deketalisation with concomitant lactonisation to produce the bicyclic lactone 15 in $83 \%$ yield.
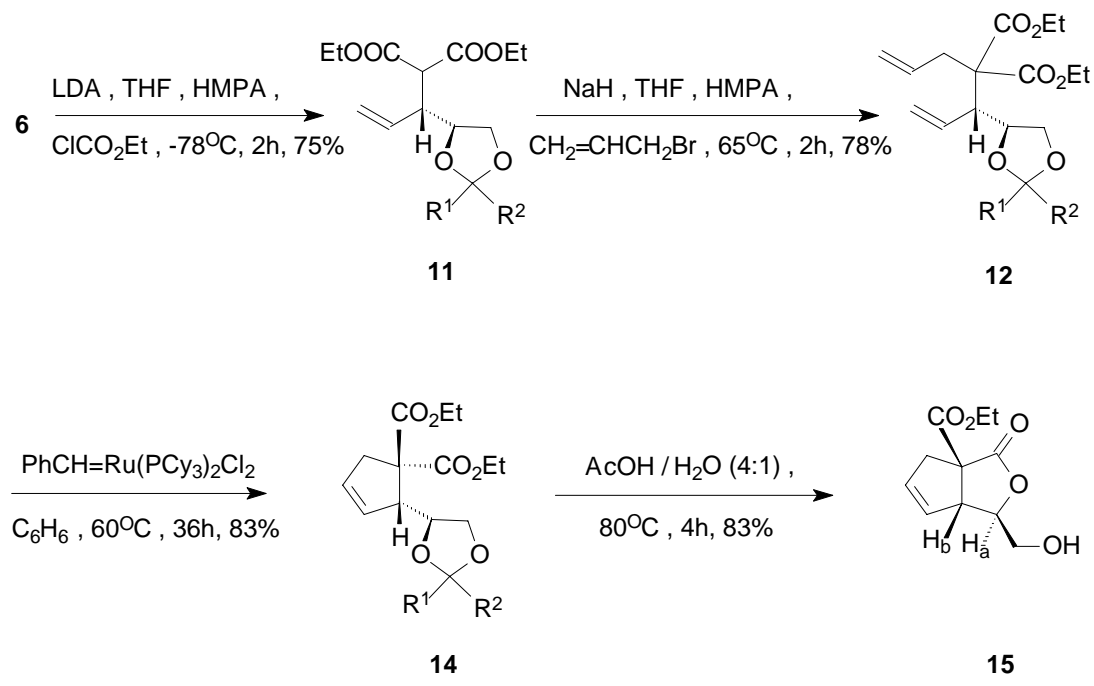

For structures 11 - $14, \mathrm{R}^{1}, \mathrm{R}^{2}=-\left(\mathrm{CH}_{2}\right)_{5}-$

\section{Scheme 3}


The unsaturated ester 10 was similarly converted to the bicyclic lactone 19 through the malonate derivative 16 (Scheme 4). The synthesis of the diene 17 through allylation of 16 followed by its RCM to produce the cyclopentene $\mathbf{1 8}$ was straightforward. The cyclopentene latter underwent smooth lactonisation when treated with $80 \%$ aqueous acetic acid to produce the lactone 19 in excellent yield.
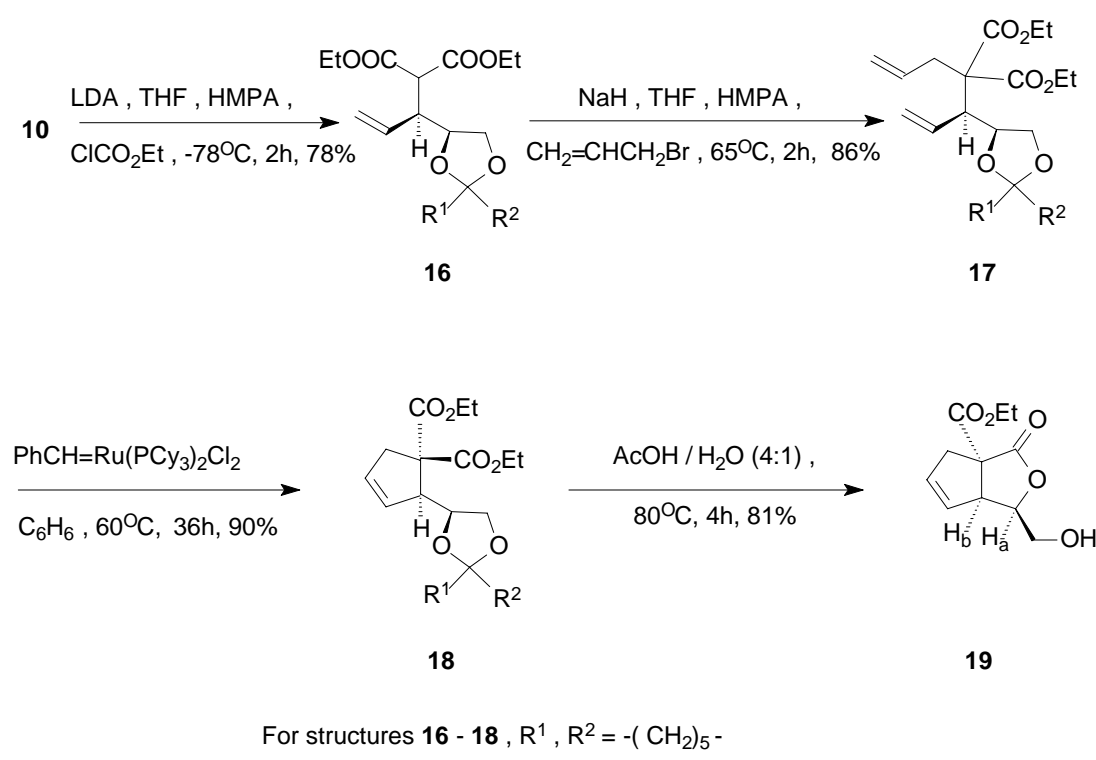

\section{Scheme 4}

The stereochemical assignment to the lactones 15 and 19 relies on comparison of the chemical shifts and coupling constants of $\mathrm{H}_{\mathrm{a}}$. Typically vicinal protons on a five-membered ring exhibit a coupling constant of at least $8 \mathrm{~Hz}$ when they are in a syn configuration, whereas the vicinal protons in an anti configuration normally exhibit a coupling constant close to zero. In the lactone 19, $\mathrm{H}_{\mathrm{a}}$ appears at $\delta 4.85$ as a dd $(J=6.12$ and $12.18 \mathrm{~Hz})$. Coupling of $\mathrm{H}_{\mathrm{a}}$ with $\mathrm{H}_{\mathrm{b}}$ gives rise to a doublet with a coupling constant of $12.18 \mathrm{~Hz}$ indicating a syn configuration. A second coupling $(J=6.12 \mathrm{~Hz})$ with the $\mathrm{CH}_{2}$ protons of $\mathrm{CH}_{2} \mathrm{OH}$ group leads to a dd (formed by merger of two triplets). On the other hand in $15, \mathrm{H}_{\mathrm{a}}$ appears at $\delta 4.40$ as a $\mathrm{dt}(\mathrm{J}=1.95$ and $4.5 \mathrm{~Hz})$. The smaller value of coupling constant $(J=1.95 \mathrm{~Hz})$ between $\mathrm{H}_{\mathrm{a}}$ and $\mathrm{H}_{\mathrm{b}}$ in 15 indicates an anti relationship between them. This is further supported by the shielding of $\mathrm{H}_{\mathrm{a}}$ proton in $\mathbf{1 5}$ by 0.45 ppm over 19. This indicates that $\mathrm{H}_{\mathrm{a}}$ lies in the shielding zone of the alkene unit in the cyclopentene ring which requires $\mathrm{H}_{\mathrm{a}}$ and cyclopentene ring to be on the same side in 15. The transformation of the esters 6 and 10 to the lactones 15 and 19 respectively also confirms the stereochemical assignment to the esters 6 and 10. The bicyclic lactones 15 and 19 represent the core structural units with the desired relative stereochemistry present in $\mathbf{1}$ and 2 respectively. Transformation of these lactones to the desired intermediate 4 requires removal of the carbethoxy group. Disappointingly, the carbethoxy group present in them could not be removed as both the lactones $\mathbf{1 5}$ and $\mathbf{1 9}$ were found to be resistant to hydrolysis or decarbethoxylation by 
Krapcho's method. The failure of $\mathbf{1 5}$ and $\mathbf{1 9}$ to undergo hydrolysis may be attributed to increase in steric crowding due to change in hybridisation state from $\mathrm{sp}^{2}$ to $\mathrm{sp}^{3}$ during hydrolysis.

In conclusion we have developed an asymmetric route for access to bacillariolides using RCM of 1, -6 -dienes built from D-mannitol as the key step. This investigation has resulted in the synthesis of bicyclic core structure of bacillariolides with correct stereochemistry.

\section{Experimental Section}

General Procedures. All reactions were carried out under an atmosphere of $\mathrm{N}_{2}$. A usual work up involves extraction of the reaction mixture with diethyl ether, washing of organic extracts with brine, drying over anhydrous $\mathrm{Na}_{2} \mathrm{SO}_{4}$ and removal of solvent at reduced pressure. Column chromatography was performed on silica gel (60-120 mesh). Petroleum refers to the fraction of petroleum ether bp 60-80 ${ }^{\circ} \mathrm{C}$. IR spectra were recorded in thin film. ${ }^{1} \mathrm{H}$ and ${ }^{13} \mathrm{C} \mathrm{NMR}$ spectra were recorded in $\mathrm{CDCl}_{3}$ solution at $300 \mathrm{MHz}$ and $75 \mathrm{MHz}$ respectively in Bruker DPX 300 . Elemental analyses were carried out at the microanalytical laboratory of this department.

Diethyl[(1R)-1-(1,4-dioxaspiro[4.5]dec-2-yl)prop-2-enyl]malonate (11). A solution of the ester $6(870 \mathrm{mg}, 3.25 \mathrm{mmol})$ in THF $(8 \mathrm{~mL})$ was added dropwise to a magnetically stirred solution of LDA [prepared from diisopropylamine $(0.91 \mathrm{~mL}, 8.12 \mathrm{mmol})$ in anhydrous THF $(3 \mathrm{~mL})$ and $\mathrm{nBuLi}\left(4.8 \mathrm{~mL}, 6.5 \mathrm{mmol}, 1.35 \mathrm{M}\right.$ in hexane)] at $-78{ }^{\circ} \mathrm{C}$. The reaction mixture was then slowly warmed to $-30{ }^{\circ} \mathrm{C}$ and stirred at that temperature for $1 \mathrm{~h}$. The reaction mixture was again cooled to $-78^{\circ} \mathrm{C}$ and to it HMPA $(0.5 \mathrm{~mL})$ followed by ethyl chloroformate $(0.37 \mathrm{~mL}$, $3.9 \mathrm{mmol})$ was added dropwise. The reaction mixture was allowed to attain $-30{ }^{\circ} \mathrm{C}$ and stirred for $2 \mathrm{~h}$. After quenching with saturated aqueous ammonium chloride solution $(1 \mathrm{~mL})$, the reaction mixture was worked up in the usual way. The crude product was purified by column chromatography using n-hexanes-ether (19:1) as eluent to afford the malonate derivative 11 $(830 \mathrm{mg}, 75 \%)$ as a colourless liquid; $[\alpha]_{\mathrm{D}}{ }^{25}+13.8\left(c 0.95, \mathrm{CHCl}_{3}\right)$; IR $v_{\max } 1736.25 \mathrm{~cm}^{-1} ;{ }^{1} \mathrm{H}$ NMR $\delta 1.23(3 \mathrm{H}, \mathrm{t}, J=7 \mathrm{~Hz}), 1.25(3 \mathrm{H}, \mathrm{t}, J=7 \mathrm{~Hz}), 1.30(2 \mathrm{H}$, br s), $1.50(4 \mathrm{H}, \mathrm{s}), 1.56(4 \mathrm{H}, \mathrm{s})$, 2.78-2.87 (1H, m), $3.61(1 \mathrm{H}, \mathrm{dd}, J=8.0,6.7 \mathrm{~Hz}), 3.76(1 \mathrm{H}, \mathrm{d}, J=5.9 \mathrm{~Hz}), 3.89(1 \mathrm{H}, \mathrm{dd}, J=8.2$, $6.0 \mathrm{~Hz}), 4.06-4.24(5 \mathrm{H}, \mathrm{m}), 5.08-5.16(2 \mathrm{H}, \mathrm{m}), 5.77-5.89(1 \mathrm{H}, \mathrm{m}) ;{ }^{13} \mathrm{C} \mathrm{NMR} \delta 14.5\left(\mathrm{CH}_{3}\right), 24.1$ $\left(\mathrm{CH}_{2}\right), 24.3\left(\mathrm{CH}_{2}\right), 25.5\left(\mathrm{CH}_{2}\right), 35.3\left(\mathrm{CH}_{2}\right), 36.8\left(\mathrm{CH}_{2}\right), 49.3(\mathrm{CH}), 53.8(\mathrm{CH}), 61.5\left(\mathrm{CH}_{2}\right), 61.7$ $\left(\mathrm{CH}_{2}\right), 68.3\left(\mathrm{CH}_{2}\right), 75.7(\mathrm{CH}), 110.6(\mathrm{C}), 120.1\left(\mathrm{CH}_{2}\right), 134.3(\mathrm{CH}), 169.0(\mathrm{CO})$. Anal. Calcd for $\mathrm{C}_{18} \mathrm{H}_{28} \mathrm{O}_{6}$ : C, 63.49; H, 8.30. Found : C, 63.77; H, 8.89.

Diethyl [(1S)-1-(1,4-dioxaspiro)[4.5]dec-2-yl)prop-2-enyl]malonate (16). Following the above procedure, the malonate derivative 16 (690 mg, 78\%) was prepared from the ester 10 (640 mg, $2.39 \mathrm{mmol}) ;[\alpha]_{\mathrm{D}}{ }^{25}+17.0\left(\mathrm{c}, 0.975, \mathrm{CHCl}_{3}\right) ; \mathrm{IR} v_{\max } 1749.3,1732.0 \mathrm{~cm}^{-1} ;{ }^{1} \mathrm{H} \mathrm{NMR} \delta 1.19(3 \mathrm{H}, \mathrm{t}$, $\mathrm{J}=7.1 \mathrm{~Hz}), 1.22(3 \mathrm{H}, \mathrm{t}, \mathrm{J}=7.1 \mathrm{~Hz}), 1.34(2 \mathrm{H}, \mathrm{br} \mathrm{s}), 1.49(4 \mathrm{H}, \mathrm{s}), 1.62(4 \mathrm{H}, \mathrm{s}), 2.89(1 \mathrm{H}, \mathrm{dt}, J=$ 9.9, $2.6 \mathrm{~Hz}), 3.61(2 \mathrm{H}, \mathrm{m}), 3.94(1 \mathrm{H}, \mathrm{t}, J=7.8 \mathrm{~Hz}), 4.06-4.26(5 \mathrm{H}, \mathrm{m}), 5.08-5.18(2 \mathrm{H}, \mathrm{m}), 5.68-$ $5.81(1 \mathrm{H}, \mathrm{m}) ;{ }^{13} \mathrm{C} \mathrm{NMR} \delta 14.40\left(\mathrm{CH}_{3}\right), 14.43\left(\mathrm{CH}_{3}\right), 24.1\left(\mathrm{CH}_{2}\right), 24.3\left(\mathrm{CH}_{2}\right), 25.5\left(\mathrm{CH}_{2}\right), 34.8$ 
$\left(\mathrm{CH}_{2}\right), 36.0\left(\mathrm{CH}_{2}\right), 46.4(\mathrm{CH}), 54.3(\mathrm{CH}), 61.7\left(\mathrm{CH}_{2}\right), 61.9\left(\mathrm{CH}_{2}\right), 66.8\left(\mathrm{CH}_{2}\right), 74.9(\mathrm{CH}), 110.0$ (C), $120.4\left(\mathrm{CH}_{2}\right), 133.3(\mathrm{CH}), 168.4(\mathrm{CO}), 168.5(\mathrm{CO})$. Anal. Calcd for $\mathrm{C}_{18} \mathrm{H}_{28} \mathrm{O}_{6}$ : C, 63.49; H, 8.30 Found : $\mathrm{C}, 63.82 ; \mathrm{H}, 8.48$.

Diethyl allyl [(1R)-1-(1,4-dioxaspiro[4.5]dec-2-yl)prop-2-enyl]malonate (12). To a magnetically stirred suspension of $\mathrm{NaH}(116 \mathrm{mg}, 2.43 \mathrm{mmol}, 50 \%$ in oil) [de-greased by repeated washing with petroleum] in THF $(2 \mathrm{~mL})$ was added dropwise a solution of the substituted malonate 11 (550 mg, $1.62 \mathrm{mmol})$ in THF (5 mL). The mixture was stirred for $2 \mathrm{~h}$ and then HMPA $(0.3 \mathrm{~mL})$ followed by allyl bromide $(0.21 \mathrm{~mL}, 2.43 \mathrm{mmol})$ was added at $\mathrm{rt}$. After refluxing for $2 \mathrm{~h}$, the reaction mixture was cooled to $\mathrm{rt}$ and quenched by adding saturated aqueous $\mathrm{NH}_{4} \mathrm{Cl}$ solution ( $1 \mathrm{~mL}$ ). A usual work-up of the reaction mixture followed by column chromatography using n-hexanes-ether (19:1) as eluent afforded the diene 12 (510 mg, 83\%) as colorless viscous liquid; $[\alpha]_{\mathrm{D}}{ }^{25}+4.4\left(c 0.9, \mathrm{CHCl}_{3}\right)$; IR: $v_{\max } 1732.0,1737.8 \mathrm{~cm}^{-1} ;{ }^{1} \mathrm{H} \mathrm{NMR} \delta$ $1.23(6 \mathrm{H}, \mathrm{t}, J=7 \mathrm{~Hz}), 1.32(2 \mathrm{H}, \mathrm{br} \mathrm{s}), 1.50(4 \mathrm{H}, \mathrm{s}), 1.52(4 \mathrm{H}, \mathrm{s}), 2.63-2.67(2 \mathrm{H}, \mathrm{m}), 2.89(1 \mathrm{H}$, dd, $J=10,7.6 \mathrm{~Hz}), 3.47(1 \mathrm{H}, \mathrm{t}, J=8 \mathrm{~Hz}), 3.84(1 \mathrm{H}, \mathrm{dd}, J=8.2,6.0 \mathrm{~Hz}), 4.18-4.3(4 \mathrm{H}, \mathrm{m}), 4.97-$ $5.19(4 \mathrm{H}, \mathrm{m}), 5.55-5.67(1 \mathrm{H}, \mathrm{m}), 5.80-5.90(1 \mathrm{H}, \mathrm{m}) ;{ }^{13} \mathrm{C} \mathrm{NMR} \delta 14.4\left(\mathrm{CH}_{3}\right), 24.2\left(\mathrm{CH}_{2}\right), 24.26$ $\left(\mathrm{CH}_{2}\right), 24.3\left(\mathrm{CH}_{2}\right), 24.3\left(\mathrm{CH}_{2}\right), 25.6\left(\mathrm{CH}_{2}\right), 35.4\left(\mathrm{CH}_{2}\right), 36.8\left(\mathrm{CH}_{2}\right), 40.2\left(\mathrm{CH}_{2}\right), 60.4(\mathrm{C}), 53.2$ $(\mathrm{CH}), 61.4\left(\mathrm{CH}_{2}\right), 61.5\left(\mathrm{CH}_{2}\right), 68.4\left(\mathrm{CH}_{2}\right), 75.1(\mathrm{CH}), 109.9(\mathrm{C}), 118.0\left(\mathrm{CH}_{2}\right), 118.6\left(\mathrm{CH}_{2}\right)$, $133.4(\mathrm{CH}), 134.4(\mathrm{CH}), 170.3(\mathrm{CO})$. Anal. Calcd for $\mathrm{C}_{21} \mathrm{H}_{32} \mathrm{O}_{6}$ : C, 66.29; H, 8.48. Found : C, 66.34; H, 8.88.

Diethyl allyl[(1S)-1-(1,4-dioxaspiro[4.5]dec-2-yl)prop-2-enyl]malonate (17). Following the above procedure, the diene 17 (340 mg, 86\%) was prepared from 16 (350 mg, $1.03 \mathrm{mmol})$; IR: $v_{\max } 1732.0 \mathrm{~cm}^{-1} ;{ }^{1} \mathrm{H}$ NMR $\delta 1.8(6 \mathrm{H}, \mathrm{t}, J=7 . \mathrm{Hz}), 1.27(2 \mathrm{H}, \mathrm{br} \mathrm{s}), 1.44(8 \mathrm{H}, \mathrm{br} \mathrm{s}), 2.56(1 \mathrm{H}, \mathrm{dd}$, $J=7.8,18 \mathrm{~Hz}), 2.67(2 \mathrm{H}, \mathrm{m}), 3.50(1 \mathrm{H}, \mathrm{t}, \mathrm{J}=8.1 \mathrm{~Hz}), 3.94-4.20(5 \mathrm{H}, \mathrm{m}), 4.45(1 \mathrm{H}, \mathrm{m}), 4.95-$ $5.04(3 \mathrm{H}, \mathrm{m}), 5.18(1 \mathrm{H}, \mathrm{dd}, \mathrm{J}=10.2,2.0 \mathrm{~Hz}), 5.57-5.60(1 \mathrm{H}, \mathrm{m}), 5.76-5.89(1 \mathrm{H}, \mathrm{m}) ;{ }^{13} \mathrm{C} \mathrm{NMR} \delta$ $14.2\left(\mathrm{CH}_{3}\right), 14.4\left(\mathrm{CH}_{3}\right), 24.2\left(\mathrm{CH}_{2}\right), 24.2\left(\mathrm{CH}_{2}\right), 25.5\left(\mathrm{CH}_{2}\right), 35.8\left(\mathrm{CH}_{2}\right), 35.9\left(\mathrm{CH}_{2}\right), 28.2\left(\mathrm{CH}_{2}\right)$, $48.8(\mathrm{CH}), 59.5(\mathrm{C}), 61.4\left(\mathrm{CH}_{2}\right), 61.8\left(\mathrm{CH}_{2}\right), 67.8\left(\mathrm{CH}_{2}\right), 74.7(\mathrm{CH}), 110.0(\mathrm{C}), 119.3\left(\mathrm{CH}_{2}\right)$, $120.3\left(\mathrm{CH}_{2}\right), 132.6(\mathrm{CH}), 133.1(\mathrm{CH}), 170.5(\mathrm{CO}), 170.9(\mathrm{CO})$.

Diethyl (2R)-2-(1,4-dioxaspiro[4.5]dec-2-yl)cyclopent-3-ene-1,1-dicarboxylate (14). A solution of the diene $12(500 \mathrm{mg}, 1.33 \mathrm{mmol})$ in anhydrous benzene $(20 \mathrm{~mL})$ was degassed by bubbling argon gas through it. To it was added Grubbs' catalyst 13 (42 mg, 4 mole\%) in one portion. The resulting pink solution was stirred at $60^{\circ} \mathrm{C}$ for $36 \mathrm{~h}$. The solvent was removed under reduced pressure, and the dark residue was purified by column chromatography using n-hexanesether $(19: 1)$ as eluent to afford the cyclopentene derivative $14(400 \mathrm{mg}, 83 \%)$; $[\alpha]_{\mathrm{D}}{ }^{25}+5.8(c$ 1.07, $\left.\mathrm{CHCl}_{3}\right)$; IR: $v_{\max } 1731.7 \mathrm{~cm}^{-1} ;{ }^{1} \mathrm{H} \mathrm{NMR} \delta 1.23(3 \mathrm{H}, \mathrm{t}, J=7 \mathrm{~Hz}), 1.25(3 \mathrm{H}, \mathrm{t}, J=7 \mathrm{~Hz}), 1.34$ $(2 \mathrm{H}$, br s), $1.49(4 \mathrm{H}, \mathrm{s}), 1.63(4 \mathrm{H}, \mathrm{s}), 2.85(1 \mathrm{H}, \mathrm{d}, J=17.3 \mathrm{~Hz}), 3.57(1 \mathrm{H}, \mathrm{d}, J=17.5 \mathrm{~Hz})$, 3.52(1H, t, $J=7.5 \mathrm{~Hz}), 3.79(1 \mathrm{H}, \mathrm{m}), 3.85-3.90(1 \mathrm{H}, \mathrm{m}), 3.99-4.24(5 \mathrm{H}, \mathrm{m}), 5.45(1 \mathrm{H}, \mathrm{br} \mathrm{s}), 5.73$ $\left(1 \mathrm{H}\right.$, br s); ${ }^{13} \mathrm{C}$ NMR $\delta 14.3\left(\mathrm{CH}_{3}\right), 14.4\left(\mathrm{CH}_{3}\right), 24.2\left(\mathrm{CH}_{2}\right), 24.3\left(\mathrm{CH}_{2}\right), 25.2\left(\mathrm{CH}_{2}\right), 35.3\left(\mathrm{CH}_{2}\right)$, $36.6\left(\mathrm{CH}_{2}\right), 40.2\left(\mathrm{CH}_{2}\right), 54.7(\mathrm{CH}), 61.9\left(\mathrm{CH}_{2}\right), 61.9\left(\mathrm{CH}_{2}\right), 62.2(\mathrm{C}), 67.2\left(\mathrm{CH}_{2}\right), 75.4(\mathrm{CH})$, $109.8(\mathrm{C}), 128.6(\mathrm{CH}), 133.3(\mathrm{CH}), 170.6(\mathrm{CO}), 172.2(\mathrm{CO})$. Anal. Calcd for $\mathrm{C}_{19} \mathrm{H}_{28} \mathrm{O}_{6}$ : C, 64.75; H, 8.00. Found : C, 64.98; H, 7.61. 
Diethyl (2S)-2-(1,4-dioxaspiro[4.5]dec-2-yl)cyclopent-3-ene-1,1-dicarboxylate (18). Following the above procedure, the cyclopentene $18(250 \mathrm{mg}, 90 \%)$ was prepared from the diene 17 (300 $\mathrm{mg}, 0.79 \mathrm{mmol})$; IR : $v_{\max } 1736 \mathrm{~cm}^{-1} ;{ }^{1} \mathrm{H} \mathrm{NMR} \delta 1.21(3 \mathrm{H}, \mathrm{t}, \mathrm{J}=7.1 \mathrm{~Hz}), 1.23(3 \mathrm{H}, \mathrm{t}, J=7 \mathrm{~Hz})$, $1.36(2 \mathrm{H}$, br s), $1.50(4 \mathrm{H}$, br s), $1.56(4 \mathrm{H}, \mathrm{m}), 2.70(1 \mathrm{H}, \mathrm{dd}, \mathrm{J}=16.9,1.6 \mathrm{~Hz}), 3.28(1 \mathrm{H}, \mathrm{dd}, \mathrm{J}=$ 16.9, $1.5 \mathrm{~Hz}), 3.62(1 \mathrm{H}, \mathrm{m}), 3.77(1 \mathrm{H}, \mathrm{dd}, \mathrm{J}=8.2,6.3 \mathrm{~Hz}), 3.99(1 \mathrm{H}, \mathrm{dd}, \mathrm{J}=8.3,6.2 \mathrm{~Hz}), 4.09$ $4.25(5 \mathrm{H}, \mathrm{m}), 5.73(2 \mathrm{H}, \mathrm{s}) ;{ }^{13} \mathrm{C} \mathrm{NMR} \delta 14.3\left(\mathrm{CH}_{3}\right), 14.4\left(\mathrm{CH}_{3}\right), 24.2\left(\mathrm{CH}_{2}\right), 24.4\left(\mathrm{CH}_{2}\right), 25.6$ $\left(\mathrm{CH}_{2}\right), 35.2\left(\mathrm{CH}_{2}\right), 36.5\left(\mathrm{CH}_{2}\right), 41.5\left(\mathrm{CH}_{2}\right), 54.7(\mathrm{CH}), 61.9\left(\mathrm{CH}_{2}\right), 61.9\left(\mathrm{CH}_{2}\right), 62.1(\mathrm{C}), 68.1$ $\left(\mathrm{CH}_{2}\right), 75.5(\mathrm{CH}), 109.8(\mathrm{C}), 129.3(\mathrm{CH}), 129.7(\mathrm{CH}), 170.4(\mathrm{CO}), 172.3(\mathrm{CO})$. Anal. Calcd for $\mathrm{C}_{19} \mathrm{H}_{28} \mathrm{O}_{6}$ : C, 64.75; H, 8.00. Found: C, 64.47; H, 8.12.

Ethyl (1S, 3aS, 6aR)-1-(hydroxymethyl)-3-oxo-4,6a-dihydro-1H-cyclopenta[c] furan3a(3H)-carboxylate (15). A solution of the cyclopentene derivative 14 (150 $\mathrm{mg}, 0.43 \mathrm{mmol})$ in aqueous acetic acid $(80 \%, 1.5 \mathrm{~mL})$ was stirred at $80{ }^{\circ} \mathrm{C}$ for $4 \mathrm{~h}$. The reaction mixture was diluted with EtOAc $(10 \mathrm{~mL})$ and washed with saturated $\mathrm{NaHCO}_{3}$ solution $(3 \times 2 \mathrm{~mL})$ to make it alkaline ( $\mathrm{pH}$ paper). The organic layer was separated and dried $\left(\mathrm{Na}_{2} \mathrm{SO}_{4}\right)$. Evaporation of the solvent under vacuum afforded a liquid which was chromatographed using n-hexanes-ether (7:3) as eluent to afford the lactone $15(80 \mathrm{mg}, 83 \%)$; $[\alpha]_{\mathrm{D}}{ }^{25}+14.6\left(\mathrm{c} 0.5, \mathrm{CHCl}_{3}\right)$; IR: $v_{\max } 3504.4$, 1774.4, $1735.8 \mathrm{~cm}^{-1} ;{ }^{1} \mathrm{H}$ NMR $\delta 1.26(3 \mathrm{H}, \mathrm{t}, \mathrm{J}=7.1 \mathrm{~Hz}), 2.56(1 \mathrm{H}$, br s), $3.09(2 \mathrm{H}, \mathrm{q}, J=$ $17.5 \mathrm{~Hz}), 3.70(1 \mathrm{H}, \mathrm{dd}, J=2.1,4.3 \mathrm{~Hz}), 3.84(2 \mathrm{H}, \mathrm{d}, J=4.2 \mathrm{~Hz}), 4.20(2 \mathrm{H}, \mathrm{q}, J=7.0 \mathrm{~Hz}), 4.40$ $(1 \mathrm{H}, \mathrm{dt}, J=1.95,4.5 \mathrm{~Hz}), 5.60(1 \mathrm{H}, \mathrm{m}), 5.76(1 \mathrm{H}, \mathrm{m}) ;{ }^{13} \mathrm{C} \mathrm{NMR} \delta 14.4\left(\mathrm{CH}_{3}\right), 42.7\left(\mathrm{CH}_{2}\right), 54.7$ $(\mathrm{CH}), 60.2(\mathrm{C}), 62.6\left(\mathrm{CH}_{2}\right), 64.5\left(\mathrm{CH}_{2}\right), 84.5(\mathrm{CH}), 131.0(\mathrm{CH}), 129.6(\mathrm{CH}), 170.5(\mathrm{CO}), 176.4$ (CO). Anal. Calcd for $\mathrm{C}_{11} \mathrm{H}_{14} \mathrm{O}_{5}: \mathrm{C}, 58.40 ; \mathrm{H}, 6.24$. Found : C, 58.55; H, 6.17.

Ethyl (1S, 3aR, 6aS)-1-(hydroxymethyl)-3-oxo-4,6a-dihydro-1H-cyclopenta [c]furan3a(3H)-carboxylate (19). Following the above procedure, the cyclopentene derivative 18 (250 mg, $0.71 \mathrm{mmol})$ was treated with $80 \%$ aqueous acetic acid to afford the lactone 19 (130 $\mathrm{mg}$, $81 \%)$ as a colorless oil; $[\alpha]_{\mathrm{D}}{ }^{25}+61\left(\mathrm{c} 0.15, \mathrm{CHCl}_{3}\right)$; IR: $v_{\max } 3438.8,1776.3,1737.7 \mathrm{~cm}^{-1} ;{ }^{1} \mathrm{H}$ NMR $\delta 1.28(3 \mathrm{H}, \mathrm{t}, J=7 \mathrm{~Hz}), 2.47(1 \mathrm{H}, \mathrm{br} \mathrm{s}), 3.04(2 \mathrm{H}, \mathrm{ddd}, J=17.5,4.4,2.1 \mathrm{~Hz}), 3.75-3.80$ $(1 \mathrm{H}, \mathrm{m}), 3.83(2 \mathrm{H}, \mathrm{d}, J=6 \mathrm{~Hz}), 4.26(2 \mathrm{H}, \mathrm{q}, J=7 \mathrm{~Hz}), 4.85(1 \mathrm{H}, \mathrm{dd}, J=6.12,12.18 \mathrm{~Hz}), 5.51-$ $5.55(1 \mathrm{H}, \mathrm{m}), 5.83-5.87(1 \mathrm{H}, \mathrm{m}) ;{ }^{13} \mathrm{C} \mathrm{NMR} \delta 14.4\left(\mathrm{CH}_{3}\right), 40.0\left(\mathrm{CH}_{2}\right), 54.7(\mathrm{CH}), 61.7(\mathrm{C}), 62.8$ $\left(\mathrm{CH}_{2}\right), 62.8\left(\mathrm{CH}_{2}\right), 82.5(\mathrm{CH}), 125.4(\mathrm{CH}), 133.3(\mathrm{CH}), 169.1(\mathrm{CO})$. Anal. Calcd for $\mathrm{C}_{11} \mathrm{H}_{14} \mathrm{O}_{5}$ : C, 58.40; H, 6.24. Found : C, 58.69; H, 6.43.

\section{Acknowledgements}

Financial support from the Department of Science and Technology, Government of India is gratefully acknowledged. SS and TB thank Council of Scientific and Industrial Research, New Delhi for research fellowships. 


\section{References}

1. (a) Wang, R.; Shimizu, Y. J. Chem. Soc., Chem. Commun. 1990, 413. (b) Wang, R.; Shimizu, Y.; Steiner, J.R.; Clardy, J. J. Chem. Soc., Chem. Commun. 1993, 379.

2. Zheng, N.; Shimizu, Y. J. Chem. Soc., Chem. Commun. 1997, 399.

3. (a) Miyaoka, H.; Tamura, M.; Yamada, Y. Tetrahedron Lett. 1988, 39, 621. (b) Seo, S.Y.; Jung, J.K.; Paek, S.M.; Lee, Y.S.; Kim, S.H.; Lee, K.O.; Suh, Y.G. Organic Lett. 2004, 6, 429.

4. (a) For reviews on the RCM reaction see : Schuster, M.; Blechert, S. Angew. Chem., Int. Ed. 1997, 36, 2036. (b) Grubbs, R.H.; Chang, S. Tetrahedron 1998, 54, 4413. (c) Pariya, C.; Jayaprakash, K.N.; Frustner, A. Angew. Chem., Int. Ed. 2000, 39, 3012. (e) Trnka, T.M.; Grubbs, R.H. Acc. Chem. Res. 2001, 34, 18. (f) Kotha, S.; Sreenivasachary, N. Indian J. Chem. 2001, 40B, 763.

5. (a) Holt, D.J.; Barker, W.D.; Jenkins, P.R.; Davies, D.L.; Garratt, S.; Fawcett, J.; Russell, D.R.; Ghosh, S. Angew. Chem., Int. Ed. 1998, 37, 3298. (b) Haque, A.; Panda, J.; Ghosh, S. Indian J. Chem. 1999, 38B, 8. (c) Holt, D.J.; Barker, W.D.; Jenkins, P.R.; Panda, J.; Ghosh, S. J. Org. Chem. 2000, 65, 482.

6. Nayek, A.; Banerjee, S.; Sinha, S.; Ghosh, S. Tetrahedron Lett. 2004, 45, 6457.

7. Chattopadhyay, A.; Mamdapur, V. R. J. Org. Chem. 1995, 60, 585.

8. Sarkar, N.; Nayek, A.; Ghosh, S. Organic Lett. 2004, 6, 1903.

9. Banerjee, S.; Ghosh, S. unpublished work from this laboratory. 